\title{
IMPROVING THE PERFORMANCE OF SMEs IN SEMARANG CITY IN THE PANDEMIC COVID 19
}

\author{
Misbakhul Arrezqi ${ }^{1}$, Bagus Yunianto Wibowo ${ }^{2}$, Eldes Willy Filatrovi ${ }^{3}$ \\ ${ }^{1,2}$ Politeknik Negeri Semarang, Semarang \\ ${ }^{3}$ Sekolah Tinggi Ilmu Ekonomi, BANK BPD JATENG, Semarang \\ Email: arrezqi@polines.ac.id, bagusyuniantowibowo@polines.ac.id, \\ eldeswillyfilatrovi@stiebankbpdjateng.ac.id
}

Abstract:

With the announcement of the regional quarantine status by President Jokowi for the increasing outbreak of the corona virus, it will indirectly have an overall impact on the economy, especially for the middle and lower class. In this case the regulation stipulated by the Government in the Health Quarantine Law states that during the area quarantine, the basic necessities of life of people living in the quarantine area are the responsibility of the Government. The social welfare of the community here is related to health, household economic conditions, a sense of security, and a good quality of life. So that people who are faced with the Covid-19 pandemic can still fulfill their basic needs and carry out their social functions. However, under these circumstances, the performance of UKM is very slow and some even collapsed. This is what made researchers investigate more deeply about the performance of SMEs during the Covid 19 pandemic.The purpose of this study was to examine the effect of entrepreneurial orientation and organizational learning on the quality of strategic assets, and also the influence of strategic asset quality on business performance. This research was conducted on SME snacks in Semarang City, the respondents used were 150 respondents. The data are processed using Structural Equation Modeling (SEM) with the help of the Analysis of Moment Structure (AMOS) version 23.0 program.Based on the results of the analysis, it is concluded that the effect of entrepreneurial orientation on the quality of strategic assets shows a $C R$ value of -0.338 and with a probability of 0.735 , testing the effect of entrepreneurial orientation on business performance shows a CR value of 2.499 and with a probability of 0.012 , testing organizational learning on the quality of strategic assets shows a value CR is 4.881 and with a probability of 0.001., Testing the effect of organizational learning on business performance shows a CR value of 1.351 and with a probability of 0.177, the effect of strategic asset quality on business performance shows a CR value of 2.067 and with a probability of 0.039 .

Keywords: $\quad$ Entrepreneurship Orientation, Organizational Learning, Strategic Asset Quality, Business Performance, SMEs, SEM 
International Journal of Economics, Business and Accounting Research (IJEBAR)

Peer Reviewed - International Journal

Vol-4, Issue-3, 2020 (IJEBAR)

E-ISSN: 2614-1280 P-ISSN 2622-4771

https://jurnal.stie-aas.ac.id/index.php/IJEBAR

\section{Introduction}

The ASEAN Economic Community (AEC / AEC, ASEAN Economic Community) which will be held in 2015 will create inevitable competition in the business world. With the existence of competition, the community must prepare preparations that can create opportunities that are supported by qualified entrepreneurship. Entrepreneurship is the process of doing something new and or different to create welfare for itself and added value for society (Kao, Kao \& Kao, 2002). Entrepreneurship can also be defined as the process of creating value by using a unique set of resources to obtain or exploit an opportunity (Morris \& Lewis, 1995). The entrepreneurial process has an attitude and behavior component. Attitude refers to the willingness of an individual or organization to seize new opportunities and to take responsibility for influencing creative change.

This research is applied to the SME sector which has a dynamic environment full of uncertainty (such as competitors, customers, suppliers, regulators, and business associations) and high competition intensity (such as prices, products, technology, distribution, human resources, and raw materials, in Rahayu. , 2009) and requires good management skills.

The role of Micro and Small Enterprises has a major contribution to Indonesia's economy and development. This sector has proven to be resilient. When the economic crisis occurred in 1998, only the Small and Medium Enterprises (SME) sector survived the economic collapse. SMEs have a strategic role in driving the economic activities of the community and become a source of income for some people in improving their welfare (Perminas princes, 2011). The failure of the economic development conglomerates that rely on large business conglomerates has prompted economic planners to shift their development efforts to focus on empowering small and medium enterprises.

The economic sector in Indonesia is the sector that contributes the most to the creation of job opportunities and sources of income, especially in low-income rural areas. Small and Medium Enterprises (SMEs), which are one component of the manufacturing sector, as a whole have a very large role in creating jobs for the community. In fact, "UKM is considered to have a strong character and relatively high resistance to crisis fluctuations" said Halim Alamsyah (Deputy Governor of BI, Infobank, 2012 No: 394: 68).

The problem in this study is due to the research gap, namely: (1) entrepreneurial orientation is stated to have a positive effect on the quality of strategic assets by Herath and Mahmood, (2013), but stated that it has a negative effect on strategic assets (Mahfooz et al., 2000), (2) The influence of organizational learning is stated to have a positive effect on the quality of strategic assets by Pujilistyani (2008) and Wijayanto (2008) but is stated to have no effect by Sudharatna and $\mathrm{Li}$ (2004), (3) entrepreneurial orientation has a positive effect on business performance according to Wilkund and Shepred (2005) and according to Slater and Naver (2000), (4) organizational learning is stated to have a positive effect on strategic asset quality by Skrinjar et al., (2007), but stated negatively on strategic assets (Chandler and Hanks, 1994); (5) Strategic asset quality is stated to have a positive effect on business performance by Muharram and Samad, (2015), but is stated to have a negative effect on business performance (Chandler and Hanks, 1994).

Based on the description as explained in the background above and the research gap, the problem in this study is how to build strategic assets with entrepreneurial orientation, and organizational learning to improve business performance in food SMEs in Semarang City. From the formulation of the problem above, the research questions are as follows:

1. How is the effect of entrepreneurial orientation on the quality of strategic assets?

2. How does organizational learning affect the quality of strategic assets?

3. How does entrepreneurial orientation affect business performance?

4. How does organizational learning affect business performance?

5. How does the quality of strategic assets affect business performance? 
International Journal of Economics, Business and Accounting Research (IJEBAR)

Peer Reviewed - International Journal

Vol-4, Issue-3, 2020 (IJEBAR)

E-ISSN: 2614-1280 P-ISSN 2622-4771

https://jurnal.stie-aas.ac.id/index.php/IJEBAR

\section{Population And Sample}

Population is a group of people, events, or everything that has certain characteristics (Indriantoro and Supomo, 1999). For this study, the population used was the owner of small SMEs in Semarang City as many as 150. Sampling in this study was carried out several specific considerations. Hair et al. 1995 (in Ferdinand, A T., 2002 p. 47) found that for the SEM model, the appropriate sample size is between 100-200. If the sample size is too large, for example 400, then the method becomes "very sensitive". The sample is the smallest part and the characteristics possessed by this population (Sugiyono, 1999). The sampling technique used in this study is a non-probability technique, non-probability sampling by means of a census. With this method, researchers used the entire population as the sample because the population was relatively small for the size in the SEM model

\section{Analysis Data}

a) Validity Test

Validity testing can be used to see the extent of accuracy and accuracy of a reliable measuring instrument. This validity test uses factor analysis. A measuring instrument is said to be valid if the Corrected item total correlation is greater than or equal to 0.4 (Singgih Santoso, 2000).

b) Reliability Test

Reliability test is a test whose purpose is to find a reliable or trustworthy measuring instrument. Reliability testing of all questions used in this study will use the Cronbach alpha formula (Cronbach alpha coefficient), which is generally considered reliable if the Cronbach alpha value is $>0.6$.

c) SEM (Structural Equatioan Modeling) test

A study requires data analysis and interpretation that aims to answer research questions in uncovering certain social phenomena. The method chosen to analyze the data must be in accordance with the research pattern and the variables to be studied. In this study, The Structural Equation Modeling (SEM) of the AMOS statistical software package is used in model development and hypothesis testing.

As a structural equation model, AMOS has been frequently used in marketing management research and strategic management. The AMOS causal model represents structural measurements and problems and is used to analyze and test hypotheses.

\section{Discussion}

Hypothesis Testing Results 1

The estimated parameter for testing the effect of entrepreneurial orientation on strategic asset quality shows a CR value of -0.338 and with a probability of 0.735 . The two values obtained did not meet the requirements for $\mathrm{H} 1$ acceptance, namely the $\mathrm{CR}$ value of -0.338 which is smaller than 1.96 and the probability of 0.735 which is greater than 0.05 . Thus, it can be concluded that entrepreneurial orientation does not have a positive effect on strategic asset quality.

Hypothesis Testing Results 2

The estimation parameter for testing the effect of entrepreneurial orientation on business performance shows a CR value of 2.499 and a probability of 0.012 . The two values obtained meet the requirements for $\mathrm{H} 2$ acceptance, namely the $\mathrm{CR}$ value of 2.499 which is greater than 1.96 and a probability of 0.012 which is smaller than 0.05 . Thus, it can be concluded that entrepreneurial orientation has a positive effect on business performance.

Hypothesis Testing Results

The estimated parameter for testing organizational learning on strategic asset quality shows a CR value of 4.881 and a probability of 0.001 . The two values obtained meet the requirements for acceptance of $\mathrm{H} 3$, namely the $\mathrm{CR}$ value of 4.881 which is greater than 1.96 and the 
International Journal of Economics, Business and Accounting Research (IJEBAR)

Peer Reviewed - International Journal

Vol-4, Issue-3, 2020 (IJEBAR)

E-ISSN: 2614-1280 P-ISSN 2622-4771

https://jurnal.stie-aas.ac.id/index.php/IJEBAR

probability of 0.001 which is smaller than 0.05 . Thus it can be concluded that organizational learning affects the quality of strategic assets.

Hypothesis Testing Results 4

The estimation parameter for testing the effect of organizational learning on business performance shows a CR value of 1.351 and a probability of 0.177 . The two values obtained do not meet the requirements for acceptance of $\mathrm{H} 4$, namely the $\mathrm{CR}$ value of 1.351 which is smaller than 1.96 and the probability of 0.177 which is greater than 0.05 . Thus it can be concluded that organizational learning has no positive effect on business performance.

Hypothesis Testing Results 5

The estimation parameter for testing the effect of strategic asset quality on business performance shows a CR value of 2.067 and a probability of 0.039 . The two values obtained meet the requirements for acceptance of $\mathrm{H} 5$, namely the $\mathrm{CR}$ value of 2.067 which is greater than 1.96 and a probability of 0.039 which is smaller than 0.05 . Thus, it can be concluded that strategic asset quality has an effect on business performance

\section{Reference}

Barney, J.B. (1991). Firm resources and sustained competitive advantage. Journal of Management, 17; 99-120.

Barney, J.B. (2004). Is the resource-based "view" a useful perspective for strategic management research? Yes. Academy of Management Review, 26, 41-56

Bharadwaj, S. G., Varadarajan, P. R., and Fahy, J., 1993, "Sustainable Competitive Advantage in Services Industries: A Conceptual Model and Research Propositions", Journal of Marketing

Chen, Cheng-Nan, 2007, The Relation among Social Capital, Entrepreneurial Orientation, Organizational Resources and Entrepreneurial Performance for New Ventures, Contemporary Management Research, National Cheng Kung University.

Droge, Cornelia \& Shownee Vickrey. (1994). "Source and Outcomes of Competitive Advantage: An Explanory Study in The Furniture Industry". Decision Sciences. p.669-689.

Djodjobo, Cynthia Vanessa dan Tawas, Hendra N., 2014, "Pengaruh Orientasi Kewirausahaan, Inovasi Produk, dan Keunggulan Bersaing Terhadap Kinerja Pemasaran Usaha Nasi Kuning Di Kota Manado", Jurnal EMBA, Vol. 2, No. 3

Elu, Wilfridus B, 2002, Manajemen Strategis Berbasis-Kompetensi: Pendekatan Integratif Dalam Membangun Keunggulan Kompetitif Berkelanjutan, STIE Perbanas Jakarta

Frank, H., Kessler, A., and Fink, M., 2010, "Entrepreneurial Orientation and Business Performance - A Replication Study", Schmlenbach Business Review

Ferdinand, Augusty. (2000). "Manajemen Pemasaran: Sebuah Pendekatan Strategy". Research Paper Series. No.01 Program Magister Manajemen Universitas Diponegoro.

Ferdinand, A. 2002, Structural Equation Modelling Dalam Penelitian Manajemen, Universitas Diponegoro, Semarang.

Ginsberg, A. (1985). Measuring changes in entrepreneurial orientation following industry deregulation: The development of a diagnostic instrument. Proceedings of the International Council of Small Business, 50-57.

Gray, B.J., Matear S. \& Matheson P.K., 2002, "Improving Service Firm Performance", Journal of Service Marketing, Vol. 16, No. 3

Hughes, M., \& Morgan, R. E. (2007). "Deconstructing the Relationship between Entrepreneurial Orientation and Business Performance at the Embryonic Stage of Firm Growth". Industrial Marketing Management,Vol. 36, 651-661.

Indriantoro, Nur \& Supomo. (1999). Metodelogi Penelitian Bisnis untuk Akuntansi dan Manajemen. BPFE. Yogyakarta. 
International Journal of Economics, Business and Accounting Research (IJEBAR)

Peer Reviewed - International Journal

Vol-4, Issue-3, 2020 (IJEBAR)

E-ISSN: 2614-1280 P-ISSN 2622-4771

https://jurnal.stie-aas.ac.id/index.php/IJEBAR

Kotler Philip, 2000, Manajemen Pemasaran di Indonesia, Jakarta: Salemba Empat.

Raju, 2002 ," The impact of service quality and marketing on financial performance in the hospital industry: an empirical examination,journal of retailing and consumer service $9334-348$.

Sekaran, Uma. 1992. Research Methods For Business: A Skill Building Approach, Secon Edition, John Willey \& Sons, Inc. New York

Kao, R. W. Y., Kao, K. R., \& Kao, R. R. (2002). Entrepreneurism: A philosophy and a sensible alternative to the market economy. London: Imperial College Press.

Koh, Hian Chye. (1997). "Testing Hypothesis of Entrepreneurial Characteristics: A Study of Hongkong MBA Students". Journal of Managerial Psychology.p.1-11.

Kohli, A.K. \& Jaworski, B.J., 1990, "Market Orientation: The Construct, Research Propositions, and Managerial Implications", Journal of Marketing, 54 